\title{
THE IMPORTANCE OF TOPONYMY OF MUGALZHARY MOUNTAIN PLOTS AND ADJACENT TERRITORIES TO THE DEVELOPMENT OF GEOTURISM
}

\author{
Akzhunus G. ABDULLINA \\ L. N. Gumilyev Eurasian National University, Department of Physical and Economical \\ Geography, 2 Mirzoyanst, 010008, Astana, Kazakhstan, e-mail: akshunus_a@mail.ru

\section{Kuat T. SAPAROV*} \\ L. N. Gumilyev Eurasian National University, Department of Physical and Economical \\ Geography, 2 Mirzoyanst, 010008, Astana, Kazakhstan, e-mail: k.sapar67@yandex.ru
}

\section{Aigul M. SERGEYEVA}

K. Zhubanov Aktobe Regional State University, Department of Geography and Tourism, Moldagulova Ave 34, 03000o, Aktobe, Kazakhstan, e-mail: aiko-sm@mail.ru

\section{Aigul Y. YEGINBAYEVA}

L. N. Gumilyev Eurasian National University, Department of Physical and Economical Geography, 2 Mirzoyanst, o10008, Astana, Kazakhstan, e-mail: aeginbaeva@mail.ru

\section{Emin ATASOY}

Uludag University, Department of Elementary Education, Faculty of Education, Gorukle Campus, Bursa, Turkey, e-mail: geograf1967@gmail.com

\begin{abstract}
Citation: Abdullina, A.G., Saparov, K.T., Sergeyeva, A.M., Yeginbayeva, A.Y. \& Atasoy, E. (2019). THE IMPORTANCE OF TOPONYMY OF MUGALZHARY MOUNTAIN PLOTS AND ADJACENT TERRITORIES TO THE DEVELOPMENT OF GEOTURISM. GeoJournal of Tourism and Geosites, 25(2), 664-674. https://doi.org/10.30892/gtg.25230-388
\end{abstract}

\begin{abstract}
The article discusses the importance of the geographical names of the physical-geographical region - the Mugolzhar mountains in the Aktobe region, for the development of tourism in this region. Nomination of place names in the area for landscape features was based on geological, natural-geographical, historical and linguistic data. The origin and etymology of the name Mugulzhary is studied by actual data. It is identified that toponyms associated with plants, fauna and with features of the natural environment prevail, their range of distribution is revealed. Space images of sites that can become tourist sites are given, with justifications for the origin and characteristics of their name.
\end{abstract}

Key words: toponyms in tourism, oronyms, hydronyms, oikonyms, landscape, geographic terms, geotourism

\footnotetext{
* Corresponding author
} 
The Importance of Toponymy of Mugalzhary Mountain

Plots and Adjacent Territories to the Development of Geoturism

\section{INTRODUCTION}

The definition of a geographic space, a part of the planetary geospace where active population functioning takes place is of paramount importance for any country, territory or region. The inclusion of a toponymic unit into the Mugalzhar tourist guidebook may be accompanied by a statement containing etymological and linguistic and culturological information about the proprivate (onym). Geographical proper names are of different nature. So the most common names in the region are those based on the properties reflecting the natural geographic dependence of the name.

Geotourism or geological tourism is a type of innovative tourism that has been developing rapidly in recent years (Ilieş \& Josan, 2009). Kazakhstan in the most successful way enters a potential region in the international tourist market to develop this activity. In the context of heightened competition, tour operators are forced to constantly expand the range of tours and excursions offered. Taking into account many physiographic factors it is difficult for Kazakhstan to compete, if not at all, with the countries who provide comfort on warm sea beaches with a mild subtropical climate. Therefore Kazakhstan in principle may be positioned with almost all alternative forms and types of tourist services which in many aspects are natural forms for Kazakhstan. According to analysts the most successful position for Kazakhstan in international tourism could be the field of ecotourism for the development of which it has almost all types of natural and recreational resources. The purpose of this work is to reveal the role of the toponyms of Mugalzhary Mountains in the formation of the tourist product. Place names are a specific information resource for the formation of tourist routes. The scientific explanation of a modern name should be presented in an entertaining and popular way. The scope and complexity of the toponymic competence for the route depends, first of all, on the degree of the toponymic study of the territory.

Toponymy is a science that studies geographical names, their origin, semantic meaning, development, current state, spelling and pronunciation. The basic and main role and purpose of a geographical name is fixation of a location on the Earth surface. In this regard the justification and the assignment of geographical names to such geographical objects as the Mugalzhar Mountains seems to be quite currently topical toponymic and therefore historical-geographical problem.

In the toponymic aspect the Mugalzhary are little studied. Mugalzhary present the southern closure of the Ural highland-and-plain country. The territory of Mugalzhary is within the geographical coordinates of $47^{\circ}$ oo $/-50^{\circ} 10 / \mathrm{N}$ and $57^{\circ} 10$ $/-60^{\circ} 30 / \mathrm{E}$ extending in the meridional direction for $360 \mathrm{~km}$, and in latitude - for $240 \mathrm{~km}$. They are separated from the South Urals by a transverse lowering along the latitude of the city of Aktobe - to the south of Khromtau town - Bogetsay settlement Araltobe settlement. Mugalzhary serve as a watershed of the Emba and Irgiz rivers, and in the north the Or river takes off. The average height of Mugalzhary is 250-350 m, and they reach the maximum height in the Berchogur mountain group (Bolshoy Boktybai) $657 \mathrm{~m}$ above sea level, and also in the double-peak Airyk mountain - $634 \mathrm{~m}$ above sea level located to the north (Verbitskaya, 1974). Mugalzhary Mountains rise predominant over the adjacent plains only $150-200 \mathrm{~m}$ high. It is mostly a hilly terrain with smooth rounded outlines but with a large spread of rocky protrusions on the tops.

\section{RESEARCH METHODS AND STUDY MATERIALS OF RESEARCH}

The object of study is the territory of the Mugalzhary mountain adjacent area. Mugalzhary Mountains stretch in the middle part of the Aktobe region (the highest point is Mount Baktybay, $657 \mathrm{~m}$ ) (Figure 1). The major part of the territory of Mugalzhary is 
occupied by such large landforms as hills, bald peaks, plains (Baimagambetov, 2012). This feature led to the functioning of many orographic names in the toponymy of the region.

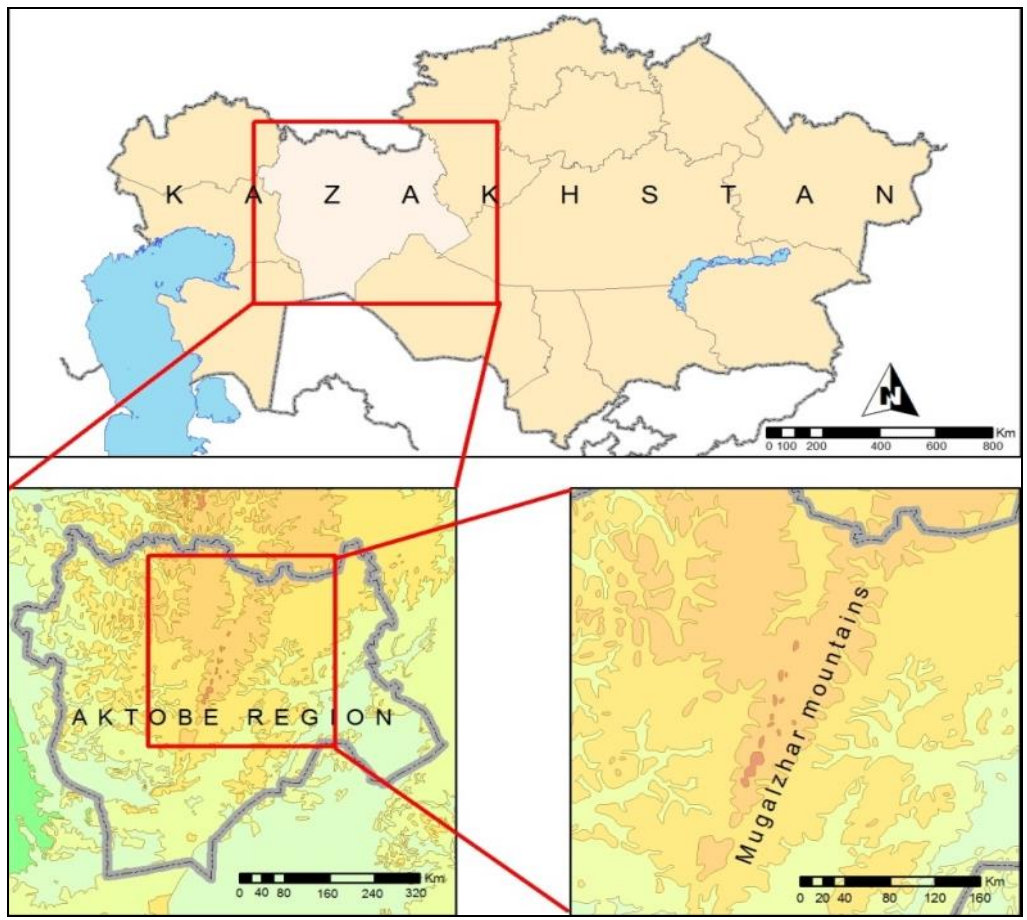

Figure 1. Location of the research territory

\section{Research methods}

During the study a descriptive method for comprehensive disclosure of the topic was used as well as a set of complementary methods: information retrieval, analysis and systematization of scientific publications and media materials on the object and subject of research, comparative method, cartographic method (using satellite imagery). The analysis of publications on the subject of the research enables us to define the concept of locality oronyms to be used in tourism. As it was noted most researchers mainly review theoretical problems of toponymy (Murzaev, 1974; Konkashpayev, 1970; Kaymuldinova, 2010; Yeginbayeva et al., 2016; A., Ilies et al., 2016, 2018), some scientists analyze various aspects of toponymy in general (Khanmagomedov \& Gebekova, 2011; Abdrakhmanov, 2012; Saparov, 2015; Saparov et al., 2017; Wendt et al., 2016; Wendt, 2017). Scientists have a long history of studying both tourism and geographical names, but rarely related to each other. Some researchers consider the use of toponyms in the interest of the tourist (Pospelov, 1988), as a tourist attraction (Light, 2014), as a potential factor of tourism development (Lemmi \& Tangheroni, 2011). The main analysis tools used were system analysis, qualitative and quantitative methods for collecting and processing information.

\section{RESULTS AND DISCUSSION}

Mugalzhary, like the whole of the Urals, is a folded region, the geosynclinal development cycle of which completed at the Early Mesozoic (Chupakhin, 1968). Mugalzhary represent the southern end of the Ural folded structure and have many 
The Importance of Toponymy of Mugalzhary Mountain

Plots and Adjacent Territories to the Development of Geoturism

features of the structure of the latter. From west to east within the region there are: PreUral marginal trough; West-Ural outer folding zone; Central Ural uplift, TagilskoMagnitogorsk trough, East Ural uplift (Mugalzhar anticlinorium); East Ural trough (Irgiz trough); Trans-Ural uplift (anticlinorium); Berchogur-Chelkar periclinal trough (Shakirov, 2012). Mugalzhary are mainly composed of heavily stationed Precambrian gneisses and crystalline schists, as well as shale, limestone, sandstone and Paleozoic conglomerates crumpled into folds (Abdullin, 1981). They are typically characterized by a sharp predominance of the meridional strike of the folds and disjunctive disorders. The presence of various intrusive and effusive igneous rocks: granites, diorites, diabases, gabbros and porphyrites is characteristic of all folding stages (Segedin, 2002). Tectonic movements in the Mesozoic and Cenozoic differed with little intensity. Epeirogenic uplift of the entire Southern Urals in the Quaternary period contributed to a certain revival of erosion processes in the Mugalzhary.

The natural originality of the Mugalzhary physiographic region is determined by the general immersion of tectonic structures in the southern direction especially observable in the extreme south, where the belt of ultrabasites developed in contrast to the more northern regions of the Urals goes within the greenstone synclinorium under the expanding periclinal trough occuring on the geosynclinal basis. In general, it can be stated that from the west to the east the thickness of volcanogenic complexes as well as the amplitude of troughs considerably decreases. The composition of depositional sequences and the age of the rocks composing them also change. So, if the Western greenstone zone is composed almost exclusively of diabasic-spilitic composition of Silurian-Devonian age, the Irgiz trough is characterized with much more developed thicks of Devonian and Lower Carboniferous sedimentary-volcanogenic rocks of various composition. Formation of the Mugalzhary's modern relief took place over a long time under the influence of various exogenous processes - marine abrasion, denudation and erosion, the intensity and direction of which at different stages of geological history was not the same and was determined by climatic conditions, the position of erosion bases, and different amplitudes and directions of tectonic movements. It resulted in the formation of a residual plain in a number of regions. The most important role was played by the diverse petrographic composition of rocks, repeatedly changing from east to west, strong physical weathering, intensive migration of weathering products from the slopes, and distance from the main local erosion bases. The highest parts of the ridge are composed of especially resistant greenstone effusive rocks like porphyry. The tops represent almost continuous bedrock exposure in the form of rocky ridges.

Modern relief preserved relics of the primary marine abrasion-accumulative surfaces in the highest parts of the watershed plateau between the basins of large rivers. The formation of these surfaces was due to repeated transgressions of the seas in the Cretaceous and Paleogene periods. Subsequently in the Neogene period the primary abrasion-accumulative surface was eroded in the places where subsequent erosion and denudation processes did not have a significant impact on it and slightly changed its original relief. The relief of central Mugalzhar clearly stands out against the background of flat steppe and territory, scrubland thicket - 5\%, open grassy landscapes - 70\%, rocky areas, bedrock exposures - 10\%, wetlands - 5\% (Chibilev \& Debelo, 2006).

Mugalzhar mountain is included in the specially protected areas of the Aktobe region on a large azonal landscape complex, characterized by diversity (Koshim et al., 2014). According to scientists, the Kazakh word mugajar means "sharp ledges located on tops" (Biyarov, 2013), others associate this name with the Turkic Mughan tribe that lived in the 1oth - 11th centuries in Central Asia and the Caucasus. From Mugand-zhar (zhar, 
jar - "precipice", "rock") Mugadjar arose ("n" fell out) (Koichybayev, 1974: 172). And A. Abdirakhmanov (2010) connects this name with the name of the tribes of Magyar (Wenger), who inhabited the Southern Urals in the 5th-9th centuries. A.K. Matveyev (1990) makes an assumption about the possibility of preserving the ethnonym "Mongol", "Mongul", "Mogul", "Mogul" as part of this name. In explaining the oronim Mugodzhary it must be taken into account that in Russian sources of the 18th century these mountains are called Mugulzhar, Mugalzhar, Magulzhar, Mugaljar (Rychkov, 1887), Mangaldirskie or Magaldir Tau, Malgazir. The "Book of the Great Drawing (1627)" introduces some information about the southern continuation of the Ural Mountains - Mugodzhary; in the source they are called the mountain Uruk or Urak: "And from the Blue (Aral) sea 300 miles off is Uruk Mountain; along Uruk there are mountains 90 miles. Three rivers flowed out of the mountain: the Vor River (Or) flows into the Yaik River ...” (Yastrebov, 1979).

Table 1. Toponyms of parts of the Mugalzhar mountain and its adjacent territories (Source: compiled by the authors on the basis of topographic scale 1: 500,000 maps)

\begin{tabular}{|c|c|c|}
\hline \begin{tabular}{|c|} 
Types of \\
toponyms
\end{tabular} & $\begin{array}{l}\text { Formation of } \\
\text { toponyms }\end{array}$ & Toponymic activity \\
\hline \multirow{4}{*}{ Oronyms } & Phyto-oronyms & Saralzhyndysai, Shibulak, Kokpektisai, Karagansai, Shagyrai \\
\hline & Zoo-oronyms & Tekelitau, Shoshkakol, Tulkiliadyr, Donyztau, Zhylandy \\
\hline & $\begin{array}{l}\text { Oronyms } \\
\text { characterizing the } \\
\text { peculiarities of } \\
\text { natural environment } \\
\text { of the area }\end{array}$ & $\begin{array}{l}\text { Shukyrtau, Zhamantau, Aktasty, Kenkuys, Sarytau, Dautau, } \\
\text { Zhalpak, Airyk, Alabas, Muzbel, Karatau, Karaoba, Obaly, } \\
\text { Akshoky, Bestobe, Koskyzylshoky, Kokzharlyasha, } \\
\text { Zhamanorkash, Alatau, Bakyrtau, Kursai, Saryoba, Birshogyr, } \\
\text { Shymyldyktau, Kurasha, Kumsai, Tassai, Karashatau, Batpakshagyl }\end{array}$ \\
\hline & Anthropo-oronyms & $\begin{array}{l}\text { Auliemola, Baimentau, Kushikbai, Shortai, Ulken Boktybai, } \\
\text { Akkarpyk, Darigershoky, Namaztau, Akkebek, Sarybaimola }\end{array}$ \\
\hline \multirow{4}{*}{ Hydronyms } & Phyto-hydronyms & $\begin{array}{l}\text { Zhosa, Ashy, Belkopa, Kyzylkaiyn, Karaagash, Kuagash, } \\
\text { Kokpekti, Olenti, Shili, Kaiyndy, Torangyly, Shagan, } \\
\text { Kamystykol, Ashykol, Shiliktikol, Karabutak, Tabantal, } \\
\text { Terisbutak, Tiekbutak, Zhosaly, Ashysai, Kiaktysai, Kyzylasha, } \\
\text { Saralzhyndy, Kaiyndy, Tikbutak, Karabutak, Uzyn-Karagandysai }\end{array}$ \\
\hline & Zoo-hydronyms & $\begin{array}{l}\text { Esekzhal, Tyshkanbulak, Shoshkakol, Shoshka, Zhaiyndy, } \\
\text { Kundyzdy, Zhaksy Kargaly, Oisylkara, Aksholak }\end{array}$ \\
\hline & $\begin{array}{l}\text { Hydronyms } \\
\text { characterizing the } \\
\text { peculiarities of } \\
\text { natural } \\
\text { environment of } \\
\text { the area }\end{array}$ & $\begin{array}{l}\text { Or, Tikasha, Akzhar, Zhamansu, Aksu, Kulasu, Aktasty, Kairakty, } \\
\text { Shuyldak, Syntas, Kosestek, Shandy, Koskol, Milysai, Zhinishke, } \\
\text { Dauyl, Araltobe, Tuzdykol, Sorkol, Solenoe, Karakol, Ulkenkol, } \\
\text { Kishkenekol, Batpakkol, Milybulak, Tastybulak, Tuzbulak, } \\
\text { Zhaltyrbulak, Bylkyldak, Bogetbulak, Bala Taldyk, Uly Taldyk, } \\
\text { Kokkudyk, Karabulak, Kurashasai, Akungirkudyk, Akbulak, Kiya, } \\
\text { Karasai, Kumkudyk, Kyzylespe, Tikasha, Aidarlyashasai, Aktastykol, } \\
\text { Koksu, Borly, Yrgiz, Shetyrgiz, Zhem, Tamdy, Akshat, Kauylzhyr }\end{array}$ \\
\hline & $\begin{array}{l}\text { Anthropo- } \\
\text { hydronyms }\end{array}$ & $\begin{array}{l}\text { Akkebek, Shot, Zhusip, Bakai, Aulie, Sadyksai, Syrlybai, Borte, } \\
\text { Kiyaly Borte, Zhezdibai, Murgelenbulak, Kilysanbulak }\end{array}$ \\
\hline \multirow[b]{2}{*}{ Oikonyms } & Phyto-oikonyms & $\begin{array}{l}\text { Kokterek, Kosterek, Taldybulak, Taldysai, Zhosaly, Kamystykol, } \\
\text { Miyalykol, Basshili, Olenti, Kopa, Terisbutak, Kaiyndy, } \\
\text { Shiliktisai, Terekti, Shilisai, Torangyly, Boztobe }\end{array}$ \\
\hline & $\begin{array}{l}\text { Oikonyms } \\
\text { characterizing the } \\
\text { peculiarities of } \\
\text { natural environment } \\
\text { of the area }\end{array}$ & $\begin{array}{l}\text { Koktau, Araltobe, Zharbutak, Sarysai, Tassai, Kairaktysai, } \\
\text { Kairakty, Ashylysai, Borly, Kumsai, Altyndy, Kotyrtas, } \\
\text { Korganzhar, Birshogyr, Bogetsai, Kyzylzhar, Aktasty, Uitas, } \\
\text { Tasotkel, Kulama, Kyzylsaz, Mugalzhar, Airyktas, Syntas, } \\
\text { Kiyaly, Bulakty, Akzhar, Ashylysai }\end{array}$ \\
\hline
\end{tabular}


The toponym Mugodzhary, or Mugodzhar Mountains (Levshin, 1996) comes into use only in the 19th century. Today the name Mugalzhar is entered on the State Catalog of Geographical Names of the Republic of Kazakhstan (2012, 2016), and on the physical map of Kazakhstan. Linguistically the name of the geographical object Mugalzhar consists of two words. The first half of the word means in the Kazakh language "muk / mok> mokalkomalyi (tukyl, mukyl)", "mukalgan, muzhilgen", destroyed, and the second half is zhar, jar - "precipice", "rock" (Zhanuzak, 2011: 185; Biyarov, 2012: 48). This designation defines the physiographic feature of Mugalzhar.

Analyzing these opinions and taking into account that according to geological data Mugolzhary is an ancient mountain, the name "mukalgan, muzhilgen" meaning" destroyed", and "zhar, jar" meaning "precipice", "rock" - are the basis of this name.

Based on the topographic map of 1: 500,000 of the Mugalzhar Mountains and their adjacent territories a total of 197 oronims, hydronyms and oikonyms were collected and systematized according to their nomination principles (Table 1). Over the course of the study it was revealed that more than $50 \%$ of the group of toponyms characterize features of the environment, terrain, and nature (landscapes) of a geographical object (Figure 2, 3).

Herewith in the name group there are more toponyms of popular geographic terms "tas", "zhar", "sai". Names with such terms are common in Saryarka with similar geological mountain orogenesis (Gorbunov, 2005; Maloletko, 1992).

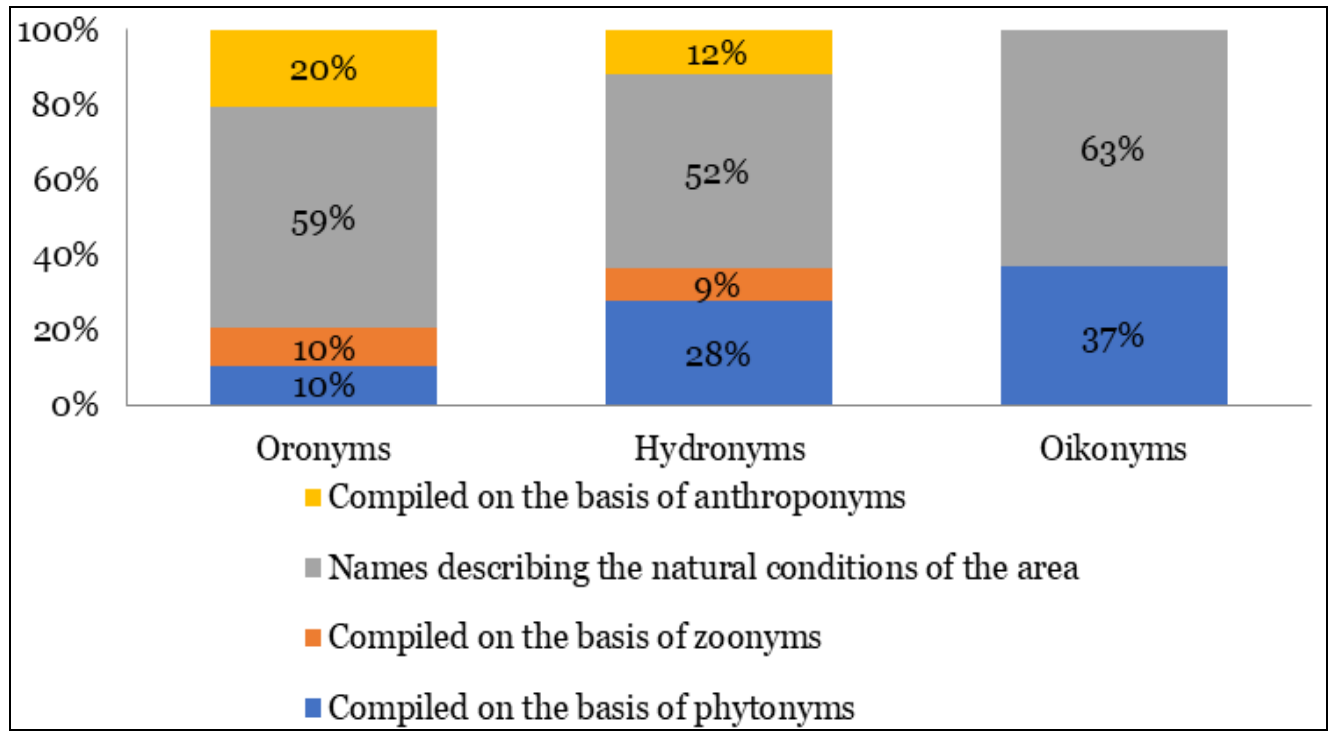

Figure 2. Features of the nomination of toponyms

of the Mugalzhar mountain sites and its adjacent territories

In the world scientific sphere of Earth sciences (geosciences: geology, geomorphology, physical geography, geotectonics, etc.) Kazakhstan is positioned as a country with a rich geological (geochronological) history, which is of great interest to the scientific community. This fact provides potential opportunities for the development of scientific tourism in the Aktobe region of the Republic of Kazakhstan represented by geotourism which in particular includes geological tourism, geomorphological tourism, and geographic tourism itself at the very beginning of the development of tourism as an industry. In the 2d-table we consider the objects of geotourism in the Mugalzhary Mountains. 
Akzhunus A. ABDULINA, Kuat T. SAPAROV, Aigul M. SERGEYEVA, Aigul Y. YEGINBAYEVA, Emin ATASOY

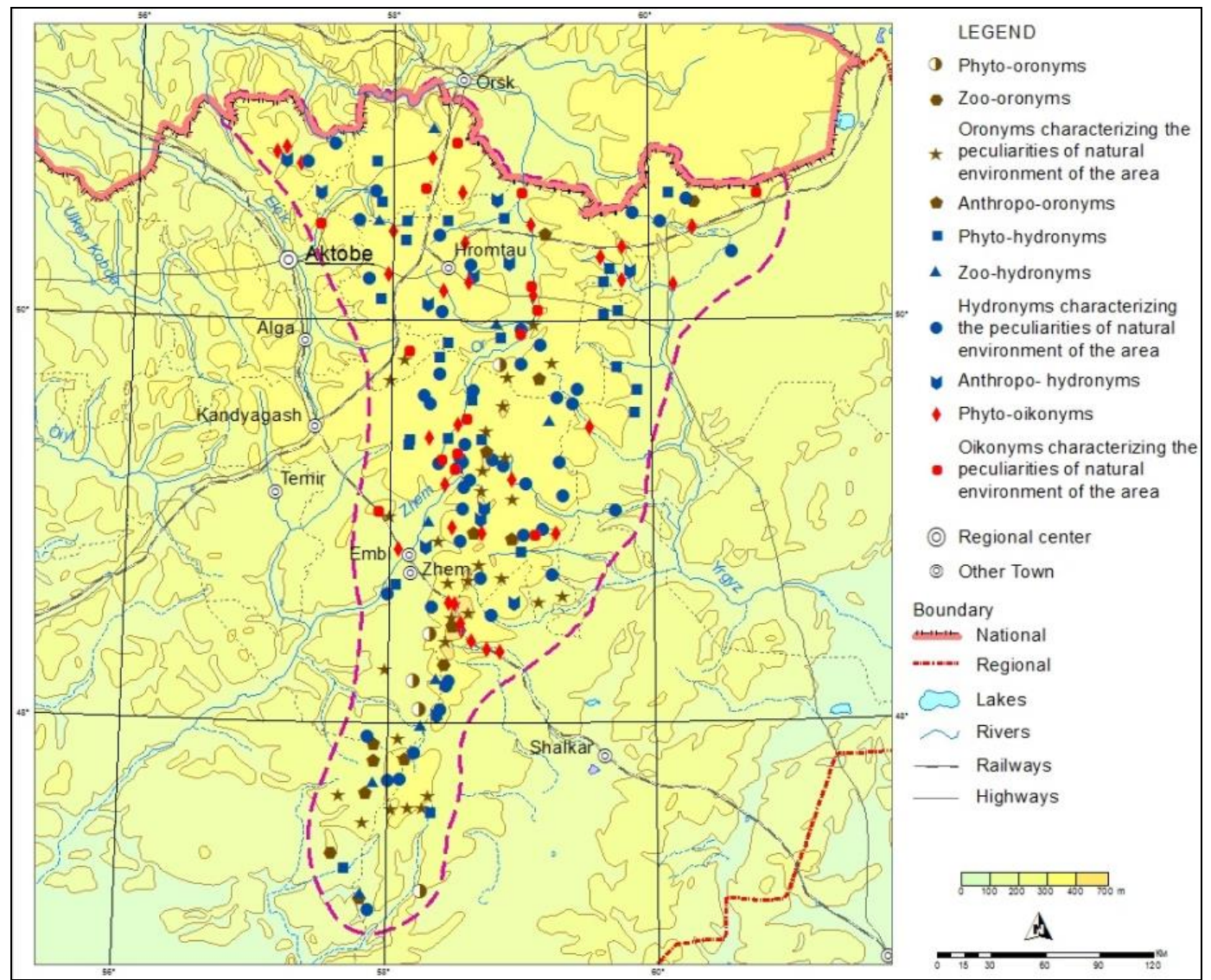

Figure 3. Map of the distribution of the toponyms of the Mugalzhar mountain sites and the adjacent territories

Table 2. The main objects of geotourism of Mugalzhary Mountains

(Source: Space photography of 2015 from Sasplanet resource)

\begin{tabular}{|l|l|}
\hline Objects of geotourism of Mugalzhar mountains & Features and role \\
\hline & $\begin{array}{l}\text { The southern end of the Ural Mountains and the } \\
\text { Mugalzhary Mountains belong to the erosion- } \\
\text { tectonic hillocky area and low mountains, } \\
\text { denudation plains of the Trans-Urals and } \\
\text { Mugalzhar. This is the most elevated region of } \\
\text { Western Kazakhstan. } \\
\text { The low mountains of the most elevated part of } \\
\text { the Western Mugalzhar are elongated in the } \\
\text { meridional direction and consist of a set of } \\
\text { sporadically located small elevations connected } \\
\text { by upfolds with weakly expressed saddles. } \\
\text { The Or-Irgiz upland or the peneplain of the } \\
\text { Eastern Mugalzhar is a vast meridionally } \\
\text { extended flat-low-slope surface. }\end{array}$ \\
\hline Mugalzhar &
\end{tabular}


The Importance of Toponymy of Mugalzhary Mountain

Plots and Adjacent Territories to the Development of Geoturism

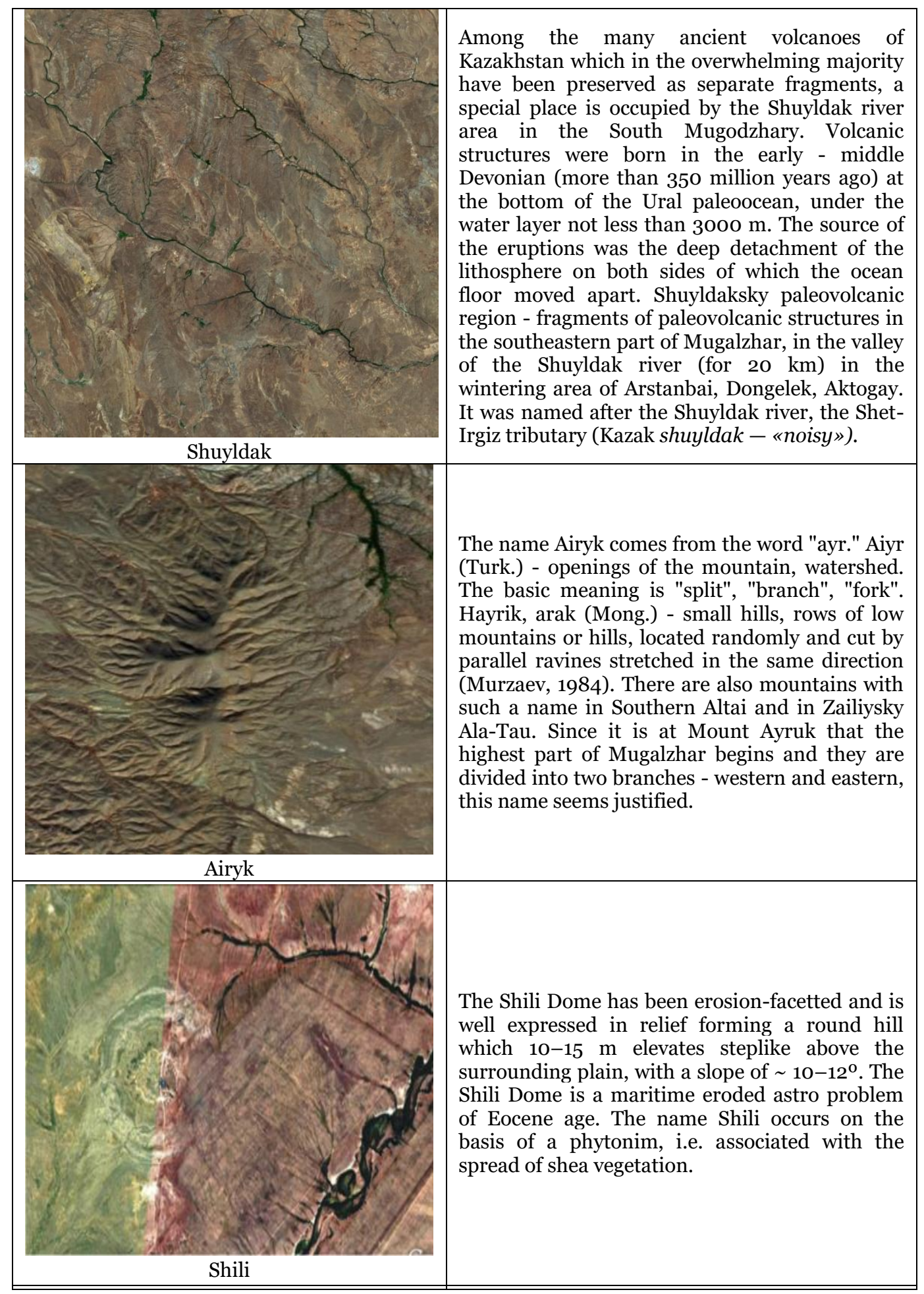




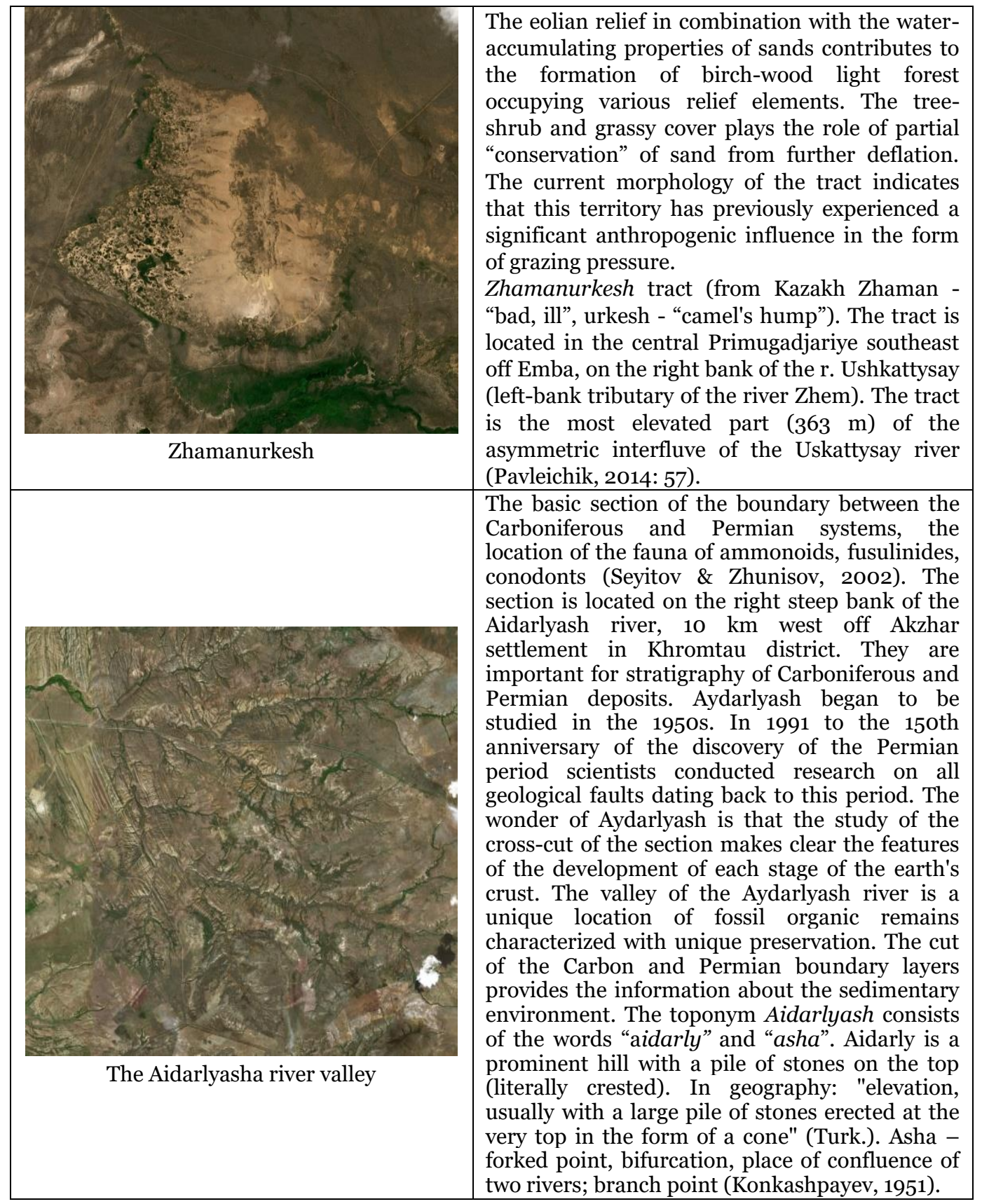

One of the promising areas of diversification of tourist services in Kazakhstan may also be the development of such a new direction in the world as geological tourism. As it is known, in terms of mining and geology Kazakhstan is a storehouse of minerals. And in the geomorphological context Kazakhstan is charaterized with almost all forms and types of Earth's surface relief. The main idea of geological tourism is familiarity with the 
The Importance of Toponymy of Mugalzhary Mountain

Plots and Adjacent Territories to the Development of Geoturism

geological and mineralogical places of interest of a region, geomorphological monuments of nature and landforms, unique landscape structures, tectonic faults, rift zones and more.

\section{CONCLUSION}

Summing up it should be said that the unique natural landscapes of Mugalzhar provide opportunities to create geo-routes and develop geotourism in the Aktobe region. And the unique geological and geomorphological objects and natural monuments of Mugalzhar Mountain are potential resources for creating and opening here a network of geoparks that have scientific, applied and educational significance for the Earth sciences, and this in turn will contribute to the development and strengthening of geotourism in the Republic of Kazakhstan.

Toponymatically prepared in this way tourists have excursions where they will consciously perceive the encountered names and also be able to verify directly on the ground whether those natural features that at one time caused the appearance of one or another name have been preserved.

In whole the geographic analysis aimed at toponymic detailing of the Mugalzhary mountain and its adjacent territories may result in the actualization of a general profound and long-term interest in Kazakhstan territories, problems and prospects for the development of tourism. At the present stage toponymic science is focused on a full and in-depth study of geographic space, the real prospect of all toponymic research in this regard is an integrative description of both structural and cognitive aspects of the toponymic situation.

\section{REFERENCES}

Abdirakhmanov, A. (2010). Toponymy and etymology, PSU after S.Toraigyrov, Pavlodar.

Abdrakhmanov, S.A. (2012). Toponymy of Kazakhstan: transliteration and etymology of names, Almaty.

Abdullin, A.A., (1981). Geology of Kazakhstan, «Nauka», Almaty, 1981, pp.303.

Baimagambetov, B.K. (2012). Geological Excursions Guide, Nobel, Aktobe.

Biyarov, B.N. (2012). Word-formation models of land - water names, the Institute of the state language development, Almaty.

Biyarov, B.N. (2013). The etymology of some macrotoponyms. History and current state of land and water names, a collection of materials of the Republican Scientific and Practical Conference, Saryarka Publishing House, Astana, pp. 81-96.

Chibilev A.A., \& Debelo P.V. (2006). Landscapes of the Ural-Caspian region, Steppe Institute UB of RAS, Dimur Printing House, Orenburg.

Chupakhin V.M. (1968). Physical geography of Kazakhstan, Nauka, Alma-Ata.

Gorbunov, A.P. (2005). Geographical names in the mountains of Central Asia, Interlegal, Almaty.

Kaymuldinova, K.D. (2010). Toponymy of Arid Regions of Kazakhstan, Te-Color Publishing House, Almaty.

Khanmagomedov, Kh.L., \& Gebekova, A.N. (2011). The study of geographical names (toponymy) and the ways of its development, in: Problems of modern science and practice, University named after VI Vernadsky. №4 (35), Tambov, pp. 24-35.

Koichybayev, E. (1974). Concise Dictionary of toponyms of Kazakhstan, Science of the Kazakh SSR, Almaty.

Konkashpayev, G.K. (1951). Kazakh folk geographical terms, in Proceedings of the Academy of Sciences of the Kaz SSR, Geographical Series, Issue 3, Alma-Ata, pp. 3-47.

Konkashpayev, G.K. (1970). General features of Turkic geographical terminology of Central Asia and Kazakhstan, in: Geography Questions, 81, Moscow, pp. 174-179.

Koshim, A.G., Sergeyeva A.M., Abdullina A.G., \& Galimov M.A. (2014). The contemporary condition of specially protected natural reservations in Aktobe Region of the republic of Kazakhstan, in: Life Science Journal, 11(5s), pp.285-288.

Ilieș, D.C., Buhas, R., Ilieș, M., Ilieș, A., Gaceu, O., Pop, A.C., Marcu, F., Buhas, S.D., Gozner, M. \& Baias, S. (2018). Sport Activities and Leisure in Nature 2000 Protected Area - Red Valley, Romania, Journal of Environmental Protection and Ecology, 19, No 1, 367-372. 


\section{Akzhunus A. ABDULINA, Kuat T. SAPAROV, Aigul M. SERGEYEVA, Aigul Y. YEGINBAYEVA, Emin ATASOY}

Ilieş, D.C., \& Josan, N. (2009). Geosites - geomorphosites and relief. GeoJournal of Tourism and Geosites, 1 (3), 78-85.

Ilieș, A., Wendt, J.A., Ilieș, D.C., Herman, G.V., Ilieș M. \& Deac A. (2016). The patrimony of wooden churches, built between 1531 and 2015, in the Land of Maramureș, Romania, Journal of Maps, 12, pp 597-602 Issue sup1 (http://dx.doi.org/10.1080/17445647.2016.1243075).

Lemmi, E., Siena, \& Tangheroni, M. (2011). The Importance of Place Names in the Sustainable Tourist Development of the Inland Areas of Tuscany: Toponyms along the Via Francigena, Names in daily life: proceedings of the XXIV ICOS International Congress of Onomastic Sciences, Barcelona, pp.1869-1879.

Levshin, A.I. (1996). Description of the Kirghiz-Cossack, or Kirghi-Kaysak hordes and steppes (ed). By M.K. Kozybaev), Sanat Publishing House, Almaty.

Light, D. (2014). Tourism and toponymy: Commodifying and Consuming Place Names, in: Tourism Geographies, 16(1), pp. 141-156.

Maloletko, A.M. (1992). Paleotoponimics, Publishing house of Tomsk University, Tomsk.

Matveyev, A.K. (1990). Tops of the Stone Belt: Names of the Ural Mountains, South Ural Book Publishing, Chelyabinsk.

Murzaev, E.M. (1970). Local geographic terms and their role in toponymy, in: Geography Questions, Mysl, Moscow, pp. 16-36

Murzaev, E.M. (1974). Toponyms Essays, Mysl, Moscow.

Pavleichik, V.M. (2014). Problems and prospects of protection of objects of the geological heritage of the Aktyubinsk region of the Republic of Kazakhstan in the "General Ural" aspect, in: Bulletin of the Voronezh State University, series: Geography. Geoecology, 2, pp. 54-61.

Pospelov, E.M. (1988). To tourists about place names, Profizdat, Moscow.

Rychkov, P.I. (1887). Topography of the Orenburg province, Breslina, Orenburg.

Saparov, K.T. (2015). Geoecological bases of toponymy, Evero Эверо Publishing House, Almaty.

Saparov, K.T., Yeginbayeva, A. Y., Nurgalieva, G. Zh., Kulzhanova, S.M., Atasoy, E. \& Wendt, J.A. (2017). The question of Kazakh national and geographical toponymic as potential factor of tourism development, GeoJournal of Tourism and Geosites, 10 (1), 115-125.

Segedin, R.A. (2002). The story about the geology of Aktobe region and the wealth of its subsoil, Aktobe.

Seyitov, N., Zhunisov, A.A. (2002). Geology of Kazakhstan, KazNTU, Almaty.

Shakirov, A.V. (2012). Physiographic features and zoning of Mugodzhar. Materials of the sixth international symposium "Geoecological problems of the steppe regions", Orenburg, pp. 805-809.

Verbitskaya, N.P. (1974). Geomorphology of the Southern Urals and Mugodzhar, Nedra, Moscow.

Yastrebov, Ye.V. (1979). Names of the Ural Mountains in the XV-XVIII centuries, in: Geography Questions, collection 110, Moscow, pp. 163-172.

Yeginbayeva, A., Saparov, K., Aralbekova, M., Atasoy, E., Kizilçaoğlu, A. \& Wendt, J.A. (2016). The role of GIS mapping method in toponomy research, in: U.Ü. Fen-Edenbiyat Falultesi Sosyal Bilimler Dergisi, 19 (30), 11-18.

Wendt, J.A. (2017). Poland: from changes of German names up to bilingual geographical names, Achieving Peace and Justice Through Geographical Naming. Issue The Society for East Sea, Seoul, p. 183-195.

Wendt, J.A., Chroń, M., Jaźwiecka, M. \& Wiskulski, T. (2016). Differences In the perception and evaluation of tourist attraction of Menorca by its residents and tourists, GeoJournal of Tourism and Geosites, 9 (1), p.21-31.

Zhanuzak, T. (2011). Land-water names, Oner, Almaty.

*** State Catalogue of Geographical Names of the Republic of Kazakhstan, (2012, 2016), Volume 13, Aktobe region, Almaty.

Submitted:

26.03.2019
Revised:

10.07.2019
Accepted and published online 30.07.2019 